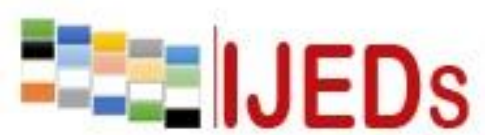

http://ijeds.ppj.unp.ac.id/index.php/IJEDS

\title{
THE EFFORTS OF IMPROVING MOTIVATION AND LEARNING OUTCOMES THROUGH THE POWER OF TWO TYPE IN THE HISTORY SUBJECT AT GRADE X IIS 3 IN SMAN 7 SOLOK SELATAN
}

\author{
${ }^{*}$ Yondri Fernando ${ }^{1}$ and Siti Fatimah ${ }^{2}$ \\ ${ }^{1}$ Postgraduate Program of Social Science, Universitas Negeri Padang, Indonesia \\ ${ }^{2}$ Lecture of Program Social Science, Universitas Negeri Padang, Indonesia \\ Email: yondrifernando18@gmail.com
}

*Corresponding Author, Received: November 12, 2019, Revised: December 10, 2019, Accepted: December 21, 2019

\begin{abstract}
This research aims to determine the efforts to improve motivation and learning outcomes through the The Power of Two type in the History Subject at grade X IIS 3 in SMAN 7 Solok Selatan. The research method used was a classroom action research. The research was conducted in SMAN 7 Solok Selatan in the second semester of the 2018/2019 academic year. The research subjects were 24 students of grade X IIS 3 . The researchwas conducted in 3 cycles: planning, action, observation and reflection phase. The data analysis technique consisted of a descriptive and qualitative analysis. The results of the research were as follows (1) The use of the The Power of Two type could increase the motivation of students of grade XI IIS 3 in SMAN 7 Solok Selatan; in the first cycle the motivation for the medium category was $49.72 \%$, increasing to $58.76 \%$; cycle II and cycle III were included in the high category with a percentage of $69.23 \%$ and (2) The use of the The Power of Two type could improve student learning outcomes of grade XI IIS 3 in SMAN 7 Solok Selatan. In the first cycle, the mean score of the student learning outcomes was unsatisfactory: 64.58 with a percentage of completeness of $12.5 \%$. Then, the second cycle increased by an mean score of 71.67 with a percentage of completeness of $20.83 \% \%$ and in the third cycle of 78.75 with a percentage of completeness $87.5 \%$.
\end{abstract}

Keywords :Learning Motivation, Learning outcomes, strategy of the Power of Two type

\section{INTRODUCTION}

The learning process is a component of education whose activities involve students and teachers. In the learning process there is an interaction between the teacher and students. The teacher has an important role during the learning process. The task of the teacher is not only transferring knowledge, not making students as learning objects 


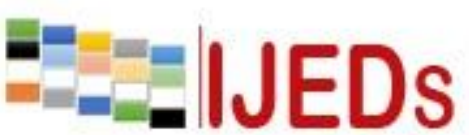

http://ijeds.ppj.unp.ac.id/index.php/IJEDS
International Journal of Educational Dynamics

Vol. 2 No. 1 (pp. 160-168) Desember 2019

p_ISSN 2655-4852

e_ISSN 2655-5093

but as learning subjects, so students are not passive and can develop knowledge appropriate with the field of study being studied. Therefore, the teacher must understand the material that will be delivered to students and be able to choose the right learning strategy in delivering the material so that student learning outcomes also improve.

In the learning process things that must be determined by the teacher are the purpose, material, strategy and evaluation. Among the four that matter is the method. The method is defined as a method or procedure used to achieve certain goals. The word "teach" itself means giving lessons (Istarani and Pulungan, 2015: 1). History as one of the social science subject currently has e various problems, especially the decrease in students' interest and motivation to learn it seriously and maximally. Decrease in students' interest and motivation in learning history should indeed be investigated first, but from observations that the authors have observed in the field indeed this phenomenon occurs. Historical subjects are not subjects that are liked ", so that a variety of opinions arise about this lesson include:" In order for history lessons to be fun and desirable, do not make history lessons only as lessons given the date of events, but students must also be emotionally involved. The learning method becomes very important in the learning process because the method can support the learning process for the better. A good learning process will lead to good student learning outcomes. In addition, the learning method can also make it easier for students to master and understand the subject matter. The teacher's task is to facilitate the learning process of students by choosing the right method with the subject matter to be taught.

The teaching and learning process is the main activity in the world of education. To achieve the success in a learning process it can be seen from optimal learning outcomes. Optimal learning outcomes are influenced by several factors, such as interests, motivation, and so on. According to Sanjaya (2008: 28), in the learning process one of the dynamic aspects that are very important is motivation. It often happens that underachievement students are not caused by lack of ability but due to lack of motivation to mobilize all of their abilities. Thus, it can be said that students with low performance are not necessarily caused by their low ability, but may be caused by the lack of motivation or motivation. Intrinsic motivation is more impressive in encouraging students to learn, but that does not mean that extrinsic motivation needs to 


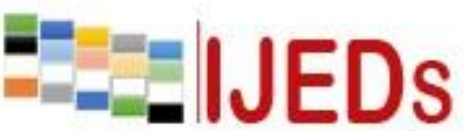

http://ijeds.ppj.unp.ac.id/index.php/IJEDS
International Journal of Educational Dynamics

Vol. 2 No. 1 (pp. 160-168) Desember 2019

p_ISSN 2655-4852

e_ISSN 2655-5093

be avoided altogether. Extrinsic motivation can provoke intrinsic motivation. Motivation can encourage students to act (as activators) and direct students to achieve learning goals. In line with Dalyono's opinion (2009: 55-60) which states "Factors that influence learning outcomes are divided into 2 groups, namely: internal factors (health, intelligence, talent, interests, motivation, ways of learning) and external factors (family, school, community and the environment).

Preliminary observations made by researchers in SMA N 7 Solok Selatan obtained from data from history subject at grade X SMA N 7 Solok Selatan, showed that the results of student history learning were not in line with expectations. This can be seen from the average student history learning outcomes in the 1st semester 1 daily tests listed in the following Table 1.

Table. 1 The Number of Students of Grade X SMA N 7 Solok Selatan on the 2018-2019 Data

The Daily Test Result 1 Semester I History Subject

\begin{tabular}{|c|c|c|c|c|c|c|}
\hline No & Class & $\begin{array}{c}\text { Total of } \\
\text { Students }\end{array}$ & KKM & Mean & $\begin{array}{c}\text { The number of } \\
\text { students under } \\
\text { the KKM }\end{array}$ & $\begin{array}{c}\text { The number of } \\
\text { students above } \\
\text { the KKM }\end{array}$ \\
\hline & X IIS 1 & 25 & 78 & 83,35 & 3 & 22 \\
\hline & X IIS 2 & 25 & 78 & 76,22 & 8 & 17 \\
\hline & X IIS 3 & 24 & 78 & 74,66 & 10 & 14 \\
\hline
\end{tabular}

Source: History subject teachers of SMA N 7 Solok Selatan)

Based on the table above it can be seen that the class which has a mean score above the KKM is only one class: X IIS 1 class with a mean score of 83.35. While the classes that have a mean score below the KKM are three classes. Of the two classes whose grades are incomplete, it turns out that class X IIS 3 has the lowest score compared to the other classes. X. IIS 3 student who are above the KKM and has the lowest score: 14 students. This indicates that there are problems in the learning process and students' motivation to follow the learning process, especially in class IIS 3 . The number of students who have not yet reached the KKM is caused by several things, including the large amount of subject matter that must be studied and the lack of students learning at home.

The observation results also found that students' motivation in the learning process was still low. The low motivation to learn was caused by several problems, 


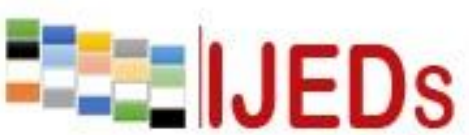

http://ijeds.ppj.unp.ac.id/index.php/IJEDS
International Journal of Educational Dynamics

Vol. 2 No. 1 (pp. 160-168) Desember 2019

p_ISSN 2655-4852

e_ISSN 2655-5093

including teacher-centered learning. Student motivation factors also contributed to the low student learning outcomes. With low motivation would cause students to be less enthusiastic in the process of finding knowledge. As argued by Muhibbin Syah (2012: 153) "Motivation is a state of internal organisms that drives it to do something or a supplier of power to behave in a directed manner. Motivation can come from within each individual and come from outside the individual.

The selection of learning strategies by teachers causes students to lack the motivation to follow the history lessons. A good method of learning history has the following characteristics: arousing great interest in the minds of students, instilling the necessary values, appropriate behavior, and work habits among students, changing the emphasis from verbal learning and memorization to learning through situations that aim concretely and real, develop teacher experiments in real classroom situations, have flexibility for the activities and participation of students, stimulate desires for further study and exploration, arouse interest in the material and techniques used by historians so students can understand how students historians write history (Kochhar translated Purwanta \& Hardiwati, 2008: 286-287).

The problems above certainly cannot be left on an ongoing basis. Therefore, teachers are required to create conditions for learning that enable students to be actively involved, so that later students can learn actively and efficiently and the expected learning objectives will be achieved. One way teachers can be used so that students can be active in the learning process is by implementing an active learning strategy.

Active learning strategies are learning strategies that can be used by students to be able to learn to cultivate their own thoughts. According to Hamalik (2009: 137) active learning in CBSA is "a way of teaching by involving maximum student activity in the learning process both intellectual mental activities, emotional activities, and physical activities in an integrated manner. Silberman (2006: 9) also argues "for learning to be active students must use a lot of the brain, study ideas, solve problems and apply what they learn". Active learning accommodates all student needs (including visual, auditory, and kinesthetic). One active learning strategy that can be used is an active learning strategy of the Power of Two type. 


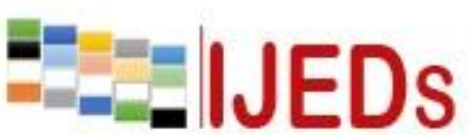

http://ijeds.ppj.unp.ac.id/index.php/IJEDS
International Journal of Educational Dynamics

Vol. 2 No. 1 (pp. 160-168) Desember 2019

p_ISSN 2655-4852

e_ISSN 2655-5093

The active learning strategy of the Power of Two type means the active learning strategy which in its application uses the power learning technique of two people (the Power of Two). Clearly, the types means the same as the technique used. Active learning strategies of the Power of Two type according to Silberman (2006: 173) are "learning strategies that involve student activities to enhance learning and emphasize the benefits of synergy, that two heads are better than one". The Power of Two type is done in every way students are given several questions that require reflection and thought, after that students are divided into small groups consisting of two people who then they are told to discuss and share knowledge about the material that has been studied.All students will be involved in the learning process so students become motivated and active in learning.

The teachers of the history subject seem less able to increase student motivation in learning. This can be seen from the lack of the teachers' attention to the students who are less active in the learning process as well as the lack of teachers' appreciation for the students who have high achievements. In addition, the teachers give less attention to the atmosphere of the classroom when the learning process.

During the learning process the students only listen, watch and record what the the teacher write on the board, so that the material taught is difficult for them to understand. Then, at the next meeting, the students tend to forget the material that has been taught before and when the teacher explains, students mostly talk to their peers. This is expected because they do not understand the material being taught. If students are given a number of questions or exercises, most students have not been able to finish and they prefer to copy or write what their friends made. Current history subject teachers use conventional learning strategies (learning is more teacher centered), use theoretical lecture methods, text books, exercises and assignments so they are less able to activate students in learning.

In addition, the teacher should know that each student has a different learning motivation. There are students who have high learning motivation; there are also those who have low learning motivation. Therefore, every teacher must be able to motivate students in learning so that the motivation that exists in each student is optimally stimulated to achieve good learning outcomes. Strong motivation in students is believed 


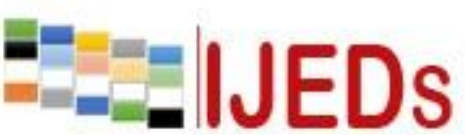

http://ijeds.ppj.unp.ac.id/index.php/IJEDS
International Journal of Educational Dynamics

Vol. 2 No. 1 (pp. 160-168) Desember 2019

p_ISSN 2655-4852

e_ISSN 2655-5093

to encourage students to work hard and never give up in facing all challenges and obstacles in learning, so that in the end it will produce optimal learning.

\section{METHOD}

This research was a quantitative research with a classroom action research conducted through the four stages that were commonly passed in PTK research: (1) planning, (2) implementation, (3) observation, and (4) reflection. The research was conducted at SMAN 7 Solok Selatan, Solok Selatan Regency in the even semester of the 2018-2019 academic years. The research subjects were 24 students of X IIS 3 class. The data analysis techniques consisted of a descriptive analysis and a quantitative and qualitative analysis.

\section{RESULTS AND DISCUSSION}

\section{Cycle I}

From the results of the first cycle of research it was found that learning has not been implemented well. This fact is still lack of interest in students with the material. This is seen during the history learning process, student motivation is low and many are unable to answer questions from the teacher. Student learning motivation in the first cycle was in moderate criteria with a percentage of $49.72 \%$. Learning outcomes obtained by students were $51-60$ scores by 14 students $(58.33 \%)$ and the students who did not complete the KKM $(<78)$ were 21 students. This means that the students who completed the cycle were 12.5\%. This appropriate with the opinion of Astuti (2013:20): (1) students are actively involved in learning, (2) students are not too dependent on the teacher; 3) increase student confidence and thinking ability; 4) students can also learn to express their ideas or ideas to others; 5) Students can learn to work together.

The implementation of learning in the first cycle is not well understood by students, so the use of The Power of Two type of learning model has not been effective. In the first cycle, it seems that the students do not have good self-confidence, so they have not been able to express ideas to others or to their partners. Each partner is still trying to understand each other's ideas.

\section{Cycle II}

The implementation of learning in cycle II can be carried out properly and systematically. Findings in the learning using the The Power of Two type can begin to 


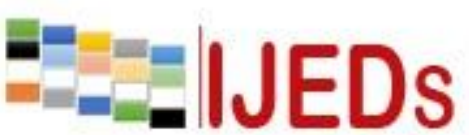

http://ijeds.ppj.unp.ac.id/index.php/IJEDS
International Journal of Educational Dynamics

Vol. 2 No. 1 (pp. 160-168) Desember 2019

p_ISSN 2655-4852

e_ISSN 2655-5093

be implemented well so that it can increase learning motivation and learning outcomes. The student motivation began to increase and included in the sufficient category with a percentage of $58.76 \%$. The student learning outcomes from a mean score of 64.58 in the first cycle increased to 71.67 in the second cycle, but the percentage of students' completeness was only $20.83 \%$. This is appropriate with Silberman's explanation (2006: 173) that a "learning strategy combines the power of two heads. Combining the two heads in this case is to form a small group, for example, each student is divided in pairs. This activity is carried out in order to create a synergy that is two heads better than one.

Increased learning motivation and learning outcomes in the second cycle above are appropriate with the advantages of The Power of Two type of learning methods, namely students are not too dependent on the teacher. The application of the steps of learning, one of them students with their partners complement each other answers to questions raised by the teacher, so that the learning process is more interesting for students.

\section{Cycle III}

The implementation of learning in cycle III can be carried out properly and systematically. As a result, the findings in learning using The Power of Two type have been implemented well so that it can increase student motivation and learning outcomes. The student learning motivation in cycle III was included in the high category with a percentage of $69.23 \%$. The learning outcomes increased from a mean score of 64.58 in the first cycle icreased to 71.67 in the second cycle and increased to 78.75 in the third cycle. The percentage of students' completeness increased to $87.5 \%$.

This is in appropriate with the opinion of Silberman (2006: 174) that in order to be able to save time in implementation, there needs to be variations, namely determining certain questions for certain pairs. This is better than each pair answering all questions.

\section{CONCLUSION}

1. The use of the The Power of Two type can improve the student motivation at grade XI IIS 3 in SMAN 7 Solok Selatan. In the first cycle the motivation of the medium 


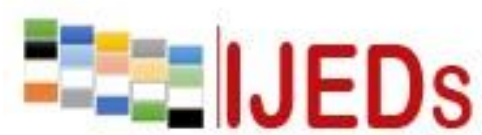

http://ijeds.ppj.unp.ac.id/index.php/IJEDS
International Journal of Educational Dynamics

Vol. 2 No. 1 (pp. 160-168) Desember 2019

p_ISSN 2655-4852

e_ISSN 2655-5093

category with a percentage of $49.72 \%$, increased to $58.76 \%$ in the second cycle and the third cycle included the high category with a percentage of $69.23 \%$.

2. The use of The Power of Two type can improve the student learning outcomes at grade XI IIS 3 SMAN 7 Solok Selatan. In the first cycle, the mean score of the student learning outcomes were unsatisfactory, that is 64.58 with a percentage of completeness of $12.5 \%$, the second cycle increased by a mean score of 71.67 with a percentage of completeness of $20.83 \% \%$ and in the third cycle a mean score of 78.75 with a percentage of completeness $87.5 \%$.

\section{REFERENCES}

BSNP. 2006. Guide to Compiling Curriculum Levels of Elementary Education at Primary and Secondary Education, Jakarta.

Dalyono, M. 2009. Educational Psychology. Jakarta. Rineka Cipta.

Darsono 2000. Learn and Learning. Semarang: IKIP Press

Dimyati and Mudjiono. 2006. Learn and Learning. Jakarta: Asdi Mahasatya

Djiwandono, Sri Esti Wuryani. 2006. Educational Psychology. Jakarta: PT. Gramedia.

Hamalik, Oemar. 2009. Teaching Planning Based on a Systems Approach. Jakarta: Earth Literacy.

Hamruni. 2012. Learning Strategies. Yogyakarta: Insan Madani Istarani \& Intan Pulungan. 2015. Encyclopedia of Education. Medan: Media Persada

Kochar, S.K. 2008 Historical Learning, Translator Purwanta and Yovita Hardiwati, Jakarta: PT Grasindo.

Mafati, Ahmad Bisyri Hadi. 2009. Learning Strategic Paper in a Cooperative Way (Field of Social Studies). http: //media.diknas.go-id. Accessed October 28,2018 .

Moleong J, Lexy. 2013. Qualitative Research Methodology. Bandung: PT Remaja Rosdakarya.

Mulyasa 2012. Become a Professional Teacher: Creating Creative and Enjoyable Learning. Bandung: PT. Teen Rosdakarya. Prayitno. 1989. Motivation in Learning. Jakarta: Educational Workforce Education

Institution Development Project.Purwanto, Ngalim. 2002. Educational Psychology. Bandung: Youth Rosda Karya

Riduwan. 2009. Measurement Scale of Research Variables. Bandung: Alfabeta

Rohani, Ahmad. 2004. Teaching Management. Jakarta: PT Rineka Cipta

Sardiman 2007. Interaction and Motivation of Teaching and Learning. Jakarta: Kharisma Putra Utama Offset

Sanjaya, Vienna. 2008. Learning in the Implementation of Competency Based Curriculum. Jakarta: Kenjana. 2009 Standard Oriented Learning Process LearningProcess.Jakarta:Kencana.

Schunk, D.H., Pintrich, P.R., \& Meece, J.L. 2005. Motivation in Education: Theory, 
http://ijeds.ppj.unp.ac.id/index.php/IJEDS Vol. 2 No. 1 (pp. 160-168) Desember 2019

Research, and Applications Third Edition. New Jersey: Pearson Education Siddiq. 2008. Learning Process. Jakarta: Earth Literacy Silberman, Melvin. 2006. Active Learning 101 Ways of Active Student Learning.

Bandung: Nusamedia.Slameto 2010. Learning and Factors That Influence It. Jakarta: PT. Rineka copyrighted.

Sudjana, Nana. 1988. The Basics of the Teaching and Learning Process. Bandung: PT. Teens Rosda Karya . 2009. Assessment of Teaching and Learning Results. Bandung: PT. Teens Rosda Karya.

Suryabrata, Sumadi. 2004. Educational Psychology. Jakarta: PT Raja Grafindo Persada Shah, Muhibbin. 2007. Learning Psychology. Jakarta: PT Raja Grafindo Persada.

Syaodih and Ibrahim. 1996. Cooperative Learning. Surabaya: Surabaya University.Press.Uno, Hamzah. B. 2008. Learning Models. Jakarta: Earth Literacy. 2009. Motivation Theory and Measurement Analysis in the Field of Education. Jakarta: Earth Literacy.

Veda, Made. 2011. Contemporary Innovative Learning Strategies. Jakarta: Earth Literacy.Winkel, WS. 1991. Psychology of Teaching. Jakarta: Grasindo 